\title{
Timeshare brand affiliation impacts
}

\section{Tammie J. Kaufman*}

Food Service and Lodging Management, Rosen College of Hospitality Management, University of Central Florida, 9907 Universal Blvd, Orlando, FL 32819, USA

E-mail: tammie.kaufman@ucf.edu

*Corresponding author

\section{Catherine Curtis}

School of Hospitality and Tourism Management, Florida International University, 3000 N.E. 151 st Street, North Miami, FL 33181, USA

E-mail: crcurtis@fiu.edu

\section{Randall S. Upchurch}

School of Hospitality Leadership, College of Management, University of Wisconsin - Stout, 415 10th Avenue, HE 443, Menomonie, WI 54751-0790, USA

E-mail: upchurchr@uwstout.edu

\begin{abstract}
Over the past two decades, internationally branded hotel companies have continued their expansion efforts into the vacation ownership/timeshare resort industry. This act of adding timeshare resorts to the parent company's already existing hotel and resort collection entailed strategic decisions that ranged from: market share, portfolio risk management and crossover financial gains. To address the association of this latter relationship, the authors surveyed vacation ownership consumers' overall satisfaction with their timeshare resort interval purchase. This was associated with the likelihood of using the parent company's traditional lodging products for business and leisure purposes. The results indicate that crossover gains do accrue from sustained consumer loyalty as portrayed by increased usage of traditional lodging providers for business and leisure purposes.
\end{abstract}

Keywords: crossover gains; timeshare ownership; brand affiliation; product satisfaction; product referral.

Reference to this paper should be made as follows: Kaufman, T.J., Curtis, C. and Upchurch, R.S. (2011) 'Timeshare brand affiliation impacts', Int. J. Built Environment and Asset Management, Vol. 1, No. 1, pp.4-13. 
Biographical notes: Tammie J. Kaufman, PhD, is an Associate Professor of Food Service and Lodging Management in the Rosen College of Hospitality Management at the University of Central Florida. Her research focus is on timeshare management as well as consumer motivation. She has co-authored a timeshare text book, Timeshare Management: The Key Issues for Hospitality Managers.

Catherine Curtis is a Visiting Assistant Professor in the School of Hospitality and Tourism Management at Florida International University. She received both MS and $\mathrm{PhD}$ degrees in Hospitality and Tourism Management from the University of Central Florida, where she taught principles of resort timesharing. Her years of experience in the hospitality industry include restaurant management, wine sales and distribution, hotels and hospitality accounting. Her research papers have been published in the Int. J. Hospitality and Tourism Administration, Journal of Foodservice Business Research, Journal of Retail and Leisure Property and Tourism Analysis.

Randall S. Upchurch is a Professor at the School of Hospitality Leadership at the University of Wisconsin-Stout. He is the previous holder of the American Resort Development Association's designation of 'Professorship in Timeshare Development'. In that role, he developed curriculum in the areas of principles of timeshare, timeshare resort operations, timeshare sales and marketing and timeshare financial strategies. He has produced over 60 academic papers with many emphasising timeshare resort development. He is also the Editor of ARDA's Timeshare Industry Resource Manual, and he is the author of Timeshare Resort Operations, an Elsevier publication.

\section{Introduction}

Vacation ownership, also known as 'timeshare', has made significant steps in becoming a preferred recreation and leisure accommodation alternative for travellers in recent years (ARDA International Foundation, 2008). The resiliency of the timeshare market during the 1980s and the earlier part of the 21st century was distinguished by an increase in timeshare resort projects, double-digit sales growth in number of units and purchasers, increased company profits, as well as the entrance of national lodging (hotels and resorts) brands into the vacation ownership market (AIF, 2010). Research conducted on behalf of the American Resort Development Association notes that sales in 2007 in the USA were $\$ 10.6$ billion. In 2007, the number of consumers in the USA encompassed 4.7 million households owning timeshare for a total of 6.5 million US timeshare intervals owned (ARDA International Foundation, 2008). The latter factor of lodging brand entry into the timeshare market legitimised the timeshare industry by heightening consumer awareness of the timeshare product as a viable and credible vacation and leisure accommodation alternative (Kaufman and Upchurch, 2007). In particular, this elevated appeal began with Marriott's entrance into the market in 1984 (Marriott Vacation Club International, 2010), and it was this company's entrance that spawned other lodging brands entering the timeshare industry as well as a sharp spike in accelerated industry growth (Upchurch and Lashley, 2006).

Given this rapid proliferation of the vacation ownership, there has been an increase in research on supply and demand characteristics with the former being the most common 
(Crotts and Ragatz, 2002; Sparks et al., 2008; Upchurch and Gruber, 2002). In early timeshare consumer research, Kaufman et al. (2006) found a significant relationship between timeshare owner satisfaction and their knowledge of various timeshare product components. Previous research conducted by Kaufman and Upchurch $(2006,2007)$ found a presence of gender differences for current usage of vacation club products, and this pattern persisted for future usage as well. What remains to be studied is the power of brand through the eyes of the vacation ownership consumer.

In summary, the aforementioned industry-sponsored studies largely concentrate on supply side concerns, while academic research has centred on associating supply side characteristics along with consumer satisfaction measurements and timeshare developer loyalty factors. This study expands this applied supply-to-demand connection with the unique focus centring on discerning timeshare consumers' impression of brand impacts as a direct their timeshare resort experiences.

\section{Literature review}

With the proliferation of new hotels into an already crowded lodging market, competition in the lodging sector has become a growing concern (Bailey and Ball, 2006). As such, customer acquisition and retention continues to challenge hotel organisations, along with the rising costs of marketing to both internal and external customers.

Especially critical for hotels is the ability to differentiate their product offerings and evoke a presence or image in the minds of customers. Many hotels have developed branding strategies not only to attract guests to their properties, but to translate their guest's stay into long-term, customer loyalty (Bailey and Ball, 2006; Cai and Hobson, 2004). Accordingly, loyal guests are typically less price-sensitive, generate additional sales by word-of-mouth and purchase more (Bailey and Ball, 2006). In an effort to further appeal to customers' purchase decisions, a number of large, branded hotels have successfully leveraged their brand name in developing new service products, which run complementary to their lodging product. One trend that can be surely seen in the hospitality industry is the strategic growth through consolidations, alliances and development of branded extensions and timeshare product offerings (Kotler et al., 2009).

Today, success in the lodging sector has been, in part, propelled by the introduction of the timeshare product. Examples of recent consolidations can be seen as follows: in 1999, Starwood Hotels acquired Vistana; in 2000, Equivest Finance purchased Peppertree Resorts and in 2001, Cendant Corporation purchased Fairfield (Upchurch and Gruber, 2002). Consequently, a number of the large, branded hospitality organisations have gained more recognition by leveraging their name in the timeshare industry through development of brand extensions. According to Weizhong et al. (2002), 'a brand extension allows firms to penetrate a variety of market segments with differentiated products that carry a single, well-established brand name'. Reputable hotel organisations such as Hilton, Marriott, Disney and Wyndham have used this branding strategy and have now become leaders in the timeshare sector (Pryce, 2002; Upchurch and Gruber, 2002).

Although some independent timeshare companies have operations throughout the USA, their numbers are much smaller and represent only around $30 \%$ of market share (Woods, 2001). Pryce (2002) confirms this point by noting there was a shift in ownership to hospitality-owned timeshare companies in the late 1990s, with six leading hotel brands 
owning timeshare operations in 1998. This attests to the growing trend of branded hotel companies in extending their brand to new service products.

While branded hotels may have the advantage of offering customers extended service products (timeshares) that evoke credibility, quality, trust and consumer confidence (Bailey and Ball, 2006; Reast, 2005; Upchurch and Gruber, 2002), there are also several risks involved. Hotel branding must deliver a consistent guest experience each time and across all branded hotels (Bailey and Ball, 2006; Mattson, 1999; Weizhong et al., 2002). Another very important factor to consider is the guests' evaluation of the extended service product to the branded parent company (Aaker and Keller, 1990; Bottomley and Holden, 2001; Nan, 2006; Reast, 2005; Van Riel et al., 2001; Weizhong et al., 2002).

Within the disciplines of marketing and psychology, there exists an abundance of brand extension literature, inclusive of studies by Nan (2006), Reast (2005), Bottomley and Holden (2001), Aaker (1990) and Aaker and Keller (1990). The focus of those studies centred upon understanding the nature of consumers' attitudes towards the parent brand and an evaluation of extended product brands vs. that of service brand extensions. In particular, Moorthi (2002) points this out in his research in which he builds upon Aaker's (1990) study of brand identity, noting the limited amount of literature addressing the branding of services. Van Riel et al. (2001) further confirm this by discussing the importance of branded-services studies and highlight the fact that very little specific research in the services context exists. However, it is readily apparent that extant literature in the services context is sparse and that research in the hospitality sector related to branding, specifically brand loyalty as it relates to the hospitality industry. An exception is a study conducted by Cai and Hobson (2004). These researchers discuss the importance of developing an integrated-branding strategy in the lodging sector. According to these authors, both academics and lodging practitioners should focus more attention on hotel branding in an effort to avoid 'becoming priced-based commodities'. Authors Olsen et al. (2005) also believe that branding is misunderstood in the lodging industry and conclude that it is too complex to be defined. Their study examines brand valuation from an accounting perspective and provides a discussion of hotel performance metrics. Several other studies have explored the topic of hotel brand equity and valuation (Bailey and Ball, 2006; Prasad and Dev, 2000). Weizhong et al. (2002) explored the relationship of brand extensions and customer loyalty within the hotel context. Unlike other branding studies, their research looked at multiple brand extensions within hotel chains and sought to determine the influence of a hotel's brand extension in promoting future stays and customer loyalty within that brand's hotel chain.

The lingering dilemma that led to the conduct of this study is that little academic research has reflected upon brand-related issues. Clearly, much is known about supply characteristics such as the number of timeshare resorts, number of villas, the number of owners and consumer interest and satisfaction with their timeshare purchase; however, there is a lack of publicly available studies reflecting upon either positive or negative gains associated with brand affiliation. Given the growth of the industry over the past 30 years as tempered by the current economic decline, there is a need to study the crossover impacts of owning a timeshare interest with that of using the parent company's (brands) traditional lodging products for business or other travel purposes. 


\subsection{Statement of purpose}

The purpose of this study is to extend past existing timeshare consumer research by discovering if brand affiliation has an impact upon a timeshare owner's ownership and expected usage of traditional hotel products for business or leisure purposes. The major assumption of this study is that a symbiotic relationship exists between the company's timeshare and hotel division. In that regard it is known that timeshare divisions actively solicit the parent company's hotel guests for purchase of their timeshare products (Upchurch and Lashley, 2006). However, what remains to be determined is the degree to which timeshare consumers perceive increased usage of traditional lodging units for business or vacation purposes, that are not being satisfied by their timeshare purchase.

\section{Study methodology}

\subsection{Methodology}

\subsubsection{Sample}

The participants were owners $(N=2,544)$ from an internationally branded timeshare company, who voluntarily participated in this study. There was an initial pool of 8,000 respondents who were randomly selected from the developer's geographical resort clusters located in the USA. Two hundred and twenty-one surveys were returned as undeliverable, which lowered the initial sample size to 7,879. As a result, the net response rate for this study was $32.2 \%(2,544 / 7,879)$. More than half of the participants approximately (55\%) were between the ages of $45-64$. Approximately $91 \%$ of the participants were in a marital relationship, and $33 \%$ of their average income was in the range $\$ 76,000-\$ 125,000$.

\subsubsection{Survey procedures}

For this project, the Dillman method of survey administration was employed. Dillman method is an industry accepted standard for mail surveys within the social science field. Under this method of survey administration, a request came from the company, stressing the importance of completing the survey and that participating in the survey was needed to find a solution to the posed problem. The researcher was portrayed as a reasonable content expert who, in light of the complexity of the problem, was assisting in this request for help, and, if forthcoming, such help will contribute to the solution of that problem. Therefore, the researcher is identified as an intermediary between the company and the members. The reward to the members by means of their involvement in the research study would help solve the problem facing them and other members who own and use this company's timeshare and hotel products. There were four basic steps to the collection of data. Firstly, all members were sent a personalised, advanced e-mail notice. The purpose of this e-mail communication informed the members that they had been selected for the survey and they would be receiving a questionnaire. This communication helped identify the purpose of the survey and therefore establish its legitimacy. Secondly, approximately one week after the e-mail message was sent, all members of the sample receive a cover letter with instructions, the questionnaire with return postage prepared and a postage pre-paid postcard used to verify their reply and request an executive 
summary of the survey results. In all cases, the replies to the surveys were anonymous. Thirdly, approximately one week after the questionnaire was mailed, a follow-up e-mail message was sent to all members of the sample. The e-mail thanked those who have already responded and requested a response from those who have not yet responded. Finally, two weeks after the reminder postcard was mailed, a new cover letter, questionnaire and e-mail message was sent out reminding everyone to participate if they had not already done so.

\subsubsection{Measures}

To measure product usage, five items were used. The researcher asked timeshare owners, "How many times have you travelled on an overnight trip for multiple nights without using your members' benefits for either vacation or business purposes during the previous year." Reliability for the five-item usage scale was over the minimum of 0.5 and is at, above or close to the acceptable level of 0.7 (Nunnally, 1978). The resulting coefficient $\alpha$ for the usage scale was 0.710 .

The dependent variable measured in this study is hotel product usage for business or travel purposes. This usage variable was measured using a five-item scale. Exploratory factor analysis (EFA) with the maximum likelihood estimation procedure was used to extract the factors and completed this in five iterations. Kaiser-Meyer-Olkin (KMO) and Bartlett's test of sphericity were run to check the appropriateness of the procedure. The KMO measured 0.630 and Bartlett's test of sphericity was significant $p<0.001$, which indicated that factor analysis was suitable. One factor was extracted from this scale and explained $46.8 \%$ of all the variable variances. Table 1 presents the results of this procedure.

The independent variable is measured by the three brand indicators of brand attraction, brand loyalty and brand value. To clarify, the concept of brand impacts in this study is described as the degree to which members were:

1 attracted to the timeshare product as a direct result of being associated with hotel company's brand name (brand attraction)

2 the degree to which being affiliated with the hotel company increased the members' likelihood of using the hotel company's hotel products (brand loyalty)

3 the degree to which the timeshare resorts added value to the hotel brand name (brand value).

Table 1 Results of EFA of product usage scale

\begin{tabular}{lcccc}
\hline Product usage & Factor loading & Communality & Eigenvalue & Variance (\%) \\
\hline Vacation purposes (branded) & 0.279 & 0.078 & 2.340 & 46.808 \\
Business purposes (branded) & 0.627 & 0.394 & & \\
Vacation purposes (non-branded) & 0.432 & 0.187 & & \\
Business purposes (non-branded) & 0.833 & 0.695 & & \\
Combination (non-branded) & 0.640 & 0.410 & & \\
\hline
\end{tabular}


Table 2 displays the means, standard deviations, reliability and inter-correlations of all variables reviewed in this study. The product usage scale and dependent variable indicated moderate to large positive correlation between the three brand impact indicators and usage of hotel products for business or vacation purposes $(r=0.484, n=2,079$, $p<0.0005)$. The net result is that these timeshare members did perceive value in using traditional hotel products for both business and vacation purposes. This implies that both accommodation products are complementary to a certain degree which leads to financial gains for both divisions.

Given the role that demographics play in the purchase of a timeshare product, the researchers conducted a hierarchical regression procedure in an effort to predict future product usage based on consumer demographic characteristics in combination with the three identified brand variables. Age, household income and marital status and the three independent variables of brand attraction, brand loyalty and brand value were entered into the model. Household income $(\beta=0.237)$, member loyalty to brand products $(\beta=0.229)$, head of household age $(\beta=-0.097)$ and brand attraction $(\beta=-0.063)$ accounted for $\sim 13 \%$ of the variance $\left(R^{2}=0.126, F=43.14\right.$, significance $\left.=0.000\right)$ in predicting product usage. It is, of course, no surprise that household income level exerted the strongest influence upon purchasing a timeshare product, seeing that this type of vacation accommodation product appeals to the availability of heightened discretionary household income levels. The fact that brand loyalty and brand attraction were part of this predictive model indicates the power of brand affiliation upon consumers' attraction to branded products (Tables 2 and 3 ).

Table 2 Descriptive statistics and correlations for all variables

\begin{tabular}{lcccccccc}
\hline Variable & Mean & $S D$ & 1 & 2 & 3 & 4 & 5 & 6 \\
\hline 1 Product & 0.000 & 0.893 & $(0.710)$ & & & & \\
$\quad$ usage & & & & & & & \\
2 Age & 3.38 & 1.05 & $-0.118^{* *}$ & & & & \\
3 Income & 3.84 & 1.73 & $0.270^{* *}$ & $-0.183^{* *}$ & & & \\
4 & Marital status & 1.14 & 0.48 & 0.025 & 0.020 & $-0.215^{* *}$ & & \\
5 Brand & 1.93 & 1.02 & 0.000 & $0.182^{* *}$ & $-0.093^{* *}$ & 0.033 & \\
& attraction & & & & & & & \\
6 Brand loyalty & 2.18 & 1.08 & $0.168^{* *}$ & $-0.132^{* *}$ & $0.055^{*}$ & 0.033 & $0.274^{* *}$ \\
7 Brand value & 1.98 & 0.99 & $0.080^{* *}$ & $0.121^{* *}$ & 0.001 & $0.072^{* *}$ & $0.484^{* *}$ & $0.433^{* *}$ \\
\hline
\end{tabular}

$* p<0.05$ level (two-tailed).

$* * p<0.01$ level (two-tailed).

Table 3 Results of hierarchical regression on expressed desire to use branded products

\begin{tabular}{lccc}
\hline Variable & $\beta$ & $R^{2}$ & $F$ \\
\hline Household income & 0.237 & & \\
Brand loyalty & 0.229 & & \\
Head of household age & -0.097 & & 43.14 \\
Brand attraction & -0.063 & 0.126 & \\
\hline
\end{tabular}




\section{Discussion and implications}

The entrance of hotel brands into the timeshare industry did not take place until the mid1980s and has persisted till date with hotel brands such as Marriott, Hilton, Hyatt, Disney, Holiday Inns, Starwood and Wyndham, assuming a significant market share during this period (Upchurch and Gruber, 2006; Upchurch and Lashley, 2006). Prior to the 1980s, the timeshare industry was dominated by independent timeshare resort developers that had no affiliation with hotel brands (AIF, 2010). The entrance of the hotel brands into the timeshare market is an important point to reflect upon because their entrance injected brand credibility, brand product standards and brand service standards, which from the consumers' perspective is the entrance of branded hotel companies into the marketplace elevating the legitimacy of the timeshare industry as a whole (Kaufman et al., 2006). In agreement with prevailing strategic management theory, the assumption is that the addition of a related product (e.g. timeshare resort) to an existing and related product line will diversify the company's product portfolio and therefore lead to higher net profits for the parent company as a whole (Kotler et al., 2009). Relative to the timeshare industry, this assumption undoubtedly has been evaluated internally, but the release of that information, other than what is gleaned from corporate stock reports for a publicly traded company, is not readily available in public venues. This assertion offers justification to studying brand impacts that accumulate from the potential crossover consumer impacts for those branded companies that operate both timeshare and hotel divisions.

The tactic of profiling timeshare consumers by their demographics is a long-standing practice exercised by both timeshare sales and marketing divisions largely due to the target marketing benefits that accrue from this process (Crotts and Ragatz, 2002; Upchurch and Lashley, 2006). The primary outcome of this consumer profiling process helps identify potential consumers who have similar characteristics with already existing members who are satisfied with the timeshare division's product and services and therefore are loyal to the company. The concept of consumer loyalty requires additional reflection in that the concept of consumer loyalty within the timeshare industry is measured by referrals, on-time payment of maintenance fees, on-time payment of consumer loans, as well as ancillary purchases offered by the developer (ARDA International Foundation, 2008; Upchurch and Lashley, 2006). Furthermore, the industry understands that target marketing efforts reduce sales and marketing costs, increase consumer satisfaction with programme offerings and results in elevated company profit margins. The net message, therefore, is that 'who they are, and why they buy' is an active process that has been in place for $\sim 30$ years within the timeshare industry. With these assumptions in mind, the finding that brand loyalty and brand attraction show a significant impact upon the timeshare consumer's desire to utilise traditional hotel products for business or leisure purposes attest to the crossover selling financial gains that accrue from timeshare ownership.

Based upon the results of this study, it is readily apparent that this company's timeshare members do see synergistic value between their timeshare ownership and lodging services offered by the brand's traditional lodging properties. In particular, the indicators of brand attraction, brand loyalty and brand value exerted a strong influence upon member desire to use the parent company's other branded traditional hotel products for business and unmet vacation needs. This act of crossover affiliation, although not directly measured in this study, bodes well for the parent company within the context that 
previous hospitality research has already shown that a linkage does exist between customer loyalty and profitability (Bowen and Chen, 2001). According to Bowen and Chen (2001), if the relationship between customer loyalty and profitability holds true, then customer retention can lead to a $25-125 \%$ profit margin increase. Needless to say, a crossover relationship of this magnitude could be quite significant for the parent company. For instance, Bowen and Shoemaker (1998) also noted that lodging guests purchased a wider variety of hotel products than non-loyal guests, loyal guests cost less to service, loyal guests purchased a higher level of food and beverage purchases while onsite and engaged in co-participation in the service delivery process. Therefore, what this study portends is the importance of continuing research that measures the impact of brand impacts associated with timeshare ownership and profitability to the parent company, either direct or indirect.

\subsection{Study limitation}

Limitations of this study may be seen in the company-specific sample, as respondents are members of a particular timeshare product. Thus, members of this branded timeshare company may not be indicative of members from other branded companies. This implicates that unique product or service strategies offered by this timeshare developer might shape brand image and therefore, serve as a moderating variable. To resolve this problem, a cross-company comparison is necessary, which is beyond the scope of this study.

\section{References}

Aaker, D. (1990) 'Brand extensions: the good, the bad, and the ugly', Sloan Management Review, Vol. 31, No. 4, pp.47-56.

Aaker, D.A. and Keller, K.L. (1990) 'Consumer evaluations of brand extensions', Journal of Marketing, Vol. 54, No. 1, pp.27-41.

ARDA International Foundation (2008) State of the Timeshare Industry. Washington, DC: American Resort Development Association.

ARDA International Foundation (AIF) (2010) Timeshare Industry Resource Manual. Washington, DC: American Resort Development Association.

Bailey, R. and Ball, S. (2006) 'An exploration of the meanings of hotel brand equity', The Services Industries Journal, Vol. 26, No. 1, pp.15-38.

Bottomley, P.A. and Holden, S.J.S. (2001) 'Do we really know how consumers evaluate brand extensions? Empirical generalizations based on secondary analysis of eight studies', Journal of Vacation Marketing, Vol. 38, No. 4, pp.494-500.

Bowen, J.T. and Chen, S.L. (2001) 'The relationship between customer loyalty and customer satisfaction', Int. J. Contemporary Hospitality Management, Vol. 13, No. 5, pp.213-217.

Bowen, J.T. and Shoemaker, S. (1998) 'Loyalty: a strategic commitment', Cornell Hospitality Quarterly, Vol. 39, No. 1, pp.12-25.

Cai, L.A. and Hobson, J.S. (2004) 'Making hotel brands work in a competitive environment', Journal of Vacation Marketing, Vol. 10, No. 3, pp.197-208.

Crotts, J. and Ragatz, R. (2002) 'Recent timeshare purchasers: who are they and why do they buy', Int. J. Hospitality Management, Vol. 21, No. 3, pp.227-238. 
Kaufman, T., Severt, D. and Upchurch, R. (2006) 'The relationship between customer satisfaction and customer awareness: the case of the vacation ownership industry', Tourism Analysis, Vol. 10, No. 4, pp.405-409.

Kaufman, T. and Upchurch, R. (2006) 'Vacation ownership: understanding the senior market', Journal of Leisure and Retail Property Management, Vol. 5, No. 2, pp.95-103.

Kaufman, T. and Upchurch, R. (2007) 'Vacation ownership: gender positioning', Journal of Leisure and Retail Property Management, Vol. 6, No. 1, pp.8-14.

Kotler, P., Bowen, J. and Makens, J. (2009) Marketing for Hospitality and Tourism (5th ed.). Upper Saddle River, NJ: Prentice Hall.

Marriott Vacation Club International (2010) Company Information. Available at: http://www. marriotttimeshare.com/default.jsp?mktcmp=int_may06_sparta_transition_vc_homemktcmp=I nt_may06_sparta_transition_vc_home\&LOC $=\overline{\mathrm{DB}} 02 * 1-1 \mathrm{C} 1 \mathrm{JWV}$.

Mattson, B. (1999) 'Boosting brand identity', National Real Estate Investor, Vol. 41, pp.14-19.

Moorthi, Y.L.R. (2002) 'An approach to branding services', The Journal of Services Marketing, Vol. 16, Nos. 2/3, pp.259-274.

Nan, X. (2006) 'Affective cues and brand extension evaluation: exploring the influence of attitude toward the parent brand and attitude toward the extension ad', Psychology \& Marketing, Vol. 23, No. 7, pp.597-616.

Nunnally, J.C. (1978) Psychometric Theory (2nd ed.). New York: McGraw-Hill.

Olsen, M.D., Chung, Y., Graf, N., Lee, K. and Madanoglu, M. (2005) 'Branding: myth and reality in the hotel industry', Journal of Retail \& Leisure Property, Vol. 4, No. 2, pp.146-162.

Prasad, K. and Dev, C.S. (2000) 'Managing hotel brand equity: a customer-centric framework for assessing performance', Cornell Hotel and Restaurant Quarterly, Vol. 41, No. 3, pp.22-31.

Pryce, A.H. (2002) 'Timeshare industry structure and competitive analysis', Int. J. Hospitality Management, Vol. 21, pp.267-275.

Reast, J.D. (2005) 'Brand trust and brand extension acceptance: the relationship', Journal of Product \& Brand Management, Vol. 14, No. 1, pp.4-13.

Sparks, B., Butcher, K. and Bradley, G. (2008) 'Dimensions and correlates of consumer value: an application to timeshare industry', Int. J. Hospitality Management, Vol. 27, No. 1, pp.98-108.

Upchurch, R.S. and Gruber, K. (2002) 'The evolution of a sleeping giant: resort timesharing', Int. J. Hospitality Management, Vol. 21, No. 3, pp.211-225.

Upchurch, R. and Lashley, C. (2006) Timeshare Resort Operations. London: ButterworthHeinemann.

van Riel, A.C.R., Lemmink, J. and Ouwersloot, H. (2001) 'Consumer evaluations of service brand extensions', Journal of Service Research, Vol. 3, No. 3, pp.220-231.

Weizhong, J., Dev, C.S. and Rao, V.R. (2002) 'Brands extension and customer loyalty', Cornell Hotel and Restaurant Administration Quarterly, Vol. 43, No. 4, pp.5-16.

Woods, R. (2001) 'Important issues for a growing timeshare industry', Cornell Hotel and Restaurant Administration Quarterly, Vol. 42, No. 1, pp.71-81. 